\title{
DRYING AND PELLET CHARACTERIZATION OF SAND- SEPARATED DAIRY MANURE FROM STEPHENVILLE, TEXAS, USA
}

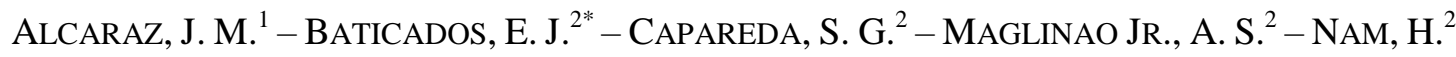 \\ ${ }^{1}$ College of Engineering, Isabela State University \\ Echague, 3309 Isabela, Philippines \\ ${ }^{2}$ Biological and Agricultural Engineering Department, Texas A\&M University \\ College Station, TX, USA \\ *Corresponding author \\ e-mail: ejnbaticados@tamu.edu \\ (Received 26 $6^{\text {th }}$ Feb 2017; accepted $6^{\text {th }}$ Jun 2017)
}

\begin{abstract}
Concentrated animal feeding operations often result in tremendous amounts of animal manure that can become a major problem to both the business and the environment. This study aims to propose an alternative use of manure for local energy generation. Dairy manure with final moisture contents ranging from $0 \%$ to $15 \%$ at $5 \%$-interval were prepared using a bench-type convection dryer inside a SHERER Environmental Chamber. The dried manure was sieved and then was pelletized using an extruder connected to an MTS Test System. The drying and physical characteristics of sand-separated manure pellets were investigated as a potential energy fuel. The average drying rate within the 20 -h drying period was measured to be at $0.025 \mathrm{~kg}$ moisture removed per $\mathrm{kg}$ of dried sample-hour. The manure pellets have $716 \mathrm{~kg} / \mathrm{m} 3 \pm 71.6 \mathrm{~kg} / \mathrm{m} 3$ bulk density with total carbon content of about $24.25 \% \pm 3.27 \%$. Removal of sand from the raw manure sample increased the heating value from $3.29 \mathrm{MJ} \mathrm{kg}^{-1}$ to $10.20 \mathrm{MJ} \mathrm{kg}^{-1}$. Sandfree manure has better elemental and fuel characteristics compared with sand-mixed as received manure from dairy farms. The resulting pellets can withstand 1.12 kilogram-force (kg-f) to $1.80 \mathrm{~kg}-\mathrm{f}$ at $5-10 \%$ $\mathrm{MC}$, which can be a candidate bioenergy fuel in terms of its over-all elemental and durability properties. Keywords: bioenergy, biomass fuel, heating value, pellet durability, waste management
\end{abstract}

\section{Introduction}

Concentrated animal feeding operations have merged into fewer, but larger operations in the U.S. animal industry. The significant increase of the number of animals per facility posed a challenge to manage enormous quantities of manure (Cantrell et al., 2007). Historically, animal manure serves as an organic fertilizer primarily because of its nutrient content. Unfortunately, inappropriate and excessive application of the animal manure can escalate concentrations of nitrogen and phosphorous compounds leading to eutrophication; contaminate groundwater sources; spread pathogens and contribute to greenhouse gas and odor pollution (Gerba and Smith, 2005).

One of the practical solutions to address the environmental and logistical problems of manure management is to reduce the water content through convective drying. It also improves handling and storage conditions, making it less susceptible to bacteriological degradation - a precursor process of noxious and offensive gases (Aboltins and Kic, 2014). The drying process reduces the moisture content (MC) down to 1-15 percent, wet basis (wb). Dried manure can generally attain high heating value of $17 \mathrm{MJ} \mathrm{kg}{ }^{-1}$ on a dry ash-free basis which can be comparable to as-received low grade coal (Mukhtar et al., 2008). 
Dairy manure is a potential cheap source of biomass energy to support local farm operations. After drying, manure can be processed into pellets that would require a low moisture content of about $8 \% \mathrm{wb}$, typical for biomass raw materials (Mani et al., 2006). Pelletizing can improve the bulk density of biomass materials by about 5 to 7 times, and helps solve typical logistics and storage problems faced by industries that mainly use solid fuels (Tumuluru et al., 2016; Biomass Energy Resource Center, 2007).

The process of pellet making usually involves molding machines like disk pelleter (dry method) and the extruder (wet method). The raw material MC greatly affects the strength and processing time of pellets for both methods (Hara, 2000). For wood pellets, increasing temperature results in stronger pellets, whereas higher $\mathrm{MC}$ results into weaker pellets (Gardner et al., 2009). In several studies conducted for grasses, the MC and compressive strengths (Mani et al., 2006; Tabil and Sokhansanj, 1996) affected the quality of pellets. The present study utilized the extruder type machine where the raw material undergoes compression into an installed pellet die.

There were a number of studies for manure pellets but primarily focused on agricultural applications. An operating moisture content of $4 \%$ to $15 \%$ of mixed manure is typical for the production of pellets. Manure pellets are considered as potential fertilizer for vegetable production in urban areas and soil ameliorant for increased crop production (Allen and Farrah, 2005; Zafari and Kianmehr, 2012). The 5\% MC pellet manure mix provided the best resistance to fragmentation when used as organic fertilizer in the field (Romano et al., 2014). Poultry litter pellets combined with bedding material was prepared within a moisture range of $6 \%$ to $22 \%$ for storage and handling (McMullen et al., 2005).

Animal waste management and income options of farmers are improved and diversified by producing dried manure pellets (EPA, 2004). Fuel pellets from dairy manure is a potential value-adding commodity for farmers, especially for those in developing countries. However, there are only few studies investigating energy pellets from swine and cattle farms. This study aims to investigate the drying and pellet characteristics of sand-separated dried dairy manure and its potential as an energy fuel.

\section{Materials and experimental methods}

\section{Manure collection and handling}

Raw manure mixed with sand came from the Southwest Regional Dairy Center in Stephenville, Texas, USA. Dairy often use sand bedding in order to promote comfort, easier management and less frequent cleaning. Selected sand materials are normally non-abrasive and fine. Dairy facilities should maintain their sand beds at full capacity at least once a week. The mixture of animal excretions and sand typically contains an initial moisture content wet basis (MCwb) of $65 \%$ to $80 \%$. The collected raw manure was transported and air-dried at the Bioenergy Testing Laboratory at Texas AandM University to reduce the moisture content up to $52-55 \% \mathrm{MCwb}$.

\section{Material preparation}

A bench-type fabricated convection dryer reduced the moisture contents of air-dried manure to the final desired levels, suitable for biomass pelleting. Using convective drying, four batches of dried manure samples with final moisture contents of $0,5,10$, 
and $15 \%$ were prepared and used for pelletizing. A blower heater with a $1.26 \mathrm{~kW}$ rating supplied the heated air at about $14 \mathrm{~L} \mathrm{~s}^{-1}$.

The dried manure undergone size reduction and sand separation. A Thomas-Wiley laboratory mill ground the sample into smaller particles. An ASTM E-11 sieve \# 45 separated and recovered the sand particles, which are normally at the range of $0.25 \mathrm{~mm}$ to $2 \mathrm{~mm}$. The recovered dried manure particles had an equivalent diameter of equal to or less than $355 \mu \mathrm{m}$. Each run utilized about $30 \mathrm{~g}$ of dried sand-separated manure for pelleting.

The sand-separated manure was loaded on the dryer and placed on a Toledo Digital Weighing Scale with an accuracy of $\pm 10 \%$. The changes in MCs were measured based on the decrease of manure weight. A one-hour interval reading was programmed using a Campbell CR 3000 data logger to monitor and record the temperature and moisture content. The convective drying was performed inside a SHERER Environmental Chamber to control the ambient conditions, particularly room temperature within 40$41^{\circ} \mathrm{C}$ range.

\section{Pellet production}

The dried sand-separated manure was loaded inside a fabricated stainless steel mold and extruded at a compression ratio of 4:1 to produce manure pellets. Each run lasted for about $40 \mathrm{~s}$. Three replicates were made for every pellet at different final moisture contents of $0,5,10$, and $15 \%$ prepared from convective drying.

\section{Characterization}

The bulk density of the dried manure sample (bone dry) was estimated after sieving. The masses and volumes of both the dried manure and the separated sand were recorded. The ratio of the total mass and volume provided an estimate of the bulk density of the dried manure sample. A Micromeritics AccuPyc 1330 was used to measure particle density. The AccuPyc is an instrument that uses a non-destructive technique of inert gas displacement to measure the volume of a known mass of solid sample. The processing time lasts for about $3 \mathrm{~min}$ and is known to produce results having $0.03 \%$ accuracy.

The weight percent composition of each elemental carbon, hydrogen, nitrogen, oxygen and sulfur $(\mathrm{C}, \mathrm{H}, \mathrm{N}, \mathrm{O}$ and $\mathrm{S})$ in the dried sand-free manure sample were analyzed using ultimate analysis according to ASTM D 3176 standard, typical for coal analysis. The sample was sieved using ASTM Sieve \#45 to produce fine manure particles. Less than $1 \mathrm{~g}$ of each replicate was used to prepare samples for ultimate analysis.

The heating value of the dried sand-free manure was measured in accordance with ASTM E 711 standard for fuel testing. A Parr bomb calorimeter 6200 was used with an installed Parr 1108 oxygen bomb to produce reliable and repeatable results at $0.1 \%$ precision. Each test was completed within $10 \mathrm{~min}$.

\section{Drying rates}

Changes in moisture content levels were monitored for every one-hour period. The periodic change in weight of the sample was assumed equal to the moisture loss. The changes in MC were monitored from the manual read out of the Toledo weighing scale. Drying operation continued for about two days until there were no changes recorded in 
the weight of the sample for four consecutive hours. A drying curve was constructed by plotting the moisture content versus time in order to estimate the drying rate of dairy manure without sand.

\section{Durability tests and analysis}

About $10 \mathrm{~g}$ of the dried sand-free manure was loaded into the pellet mold and compressed for $5 \mathrm{~min}$ to produce pellets. The pellet compressive strength was tested using an MTS 810 Material Testing system. Three pellets made for every final moisture content and tested for the durability to withstand increasing compression force. The MTS instrument induces compression with an increasing rate of around $0.05 \%$ of the initial force applied. A single-factor analysis of variance (ANOVA) was conducted to evaluate any statistical difference between the different final moisture contents of the pellets in relation to their compressive strengths. A normal quantile plot was generated to assess the normal distribution of the parameters within the $95 \%$ confidence region. The ordered differences between means were tested using t-test. Positive values show pair of means that are significantly different. The values $\mathrm{P}<0.05$ were considered statistically significant. JMP interactive statistical software by the SAS Institute Inc. was used for the statistical analysis.

\section{Results and discussion}

\section{Particle density}

Bedding stalls often use sand in typical dairy farm operations. However, the resulting sand-laden dairy manure (SLDN) becomes a constraint in maximizing manure-handling goals (Gooch and Wedel, 2002). Sand is usually removed to increase handling capacity, avoid equipment wear, clogging of transport channels and pre-treatment prior to further processing, such as for bioenergy production (Grimberg, 2008).

Table 1 shows the manure-to-sand ratio is 1:4 on a bone dry basis. The estimated apparent bulk density of the dried dairy manure was $716 \mathrm{~kg} \mathrm{~m}^{-3}$. The density results are typical of biomass pellets but higher compared to pellets prepared from sawdust $\left(606 \mathrm{~kg} \mathrm{~m}^{-3}\right)$, logging leftovers $\left(552 \mathrm{~kg} \mathrm{~m}^{-3}\right)$, corn stover $\left(550 \mathrm{~kg} \mathrm{~m}^{-3}\right)$ and switchgrass $\left(445 \mathrm{~kg} \mathrm{~m}^{-3}\right)$ (Ciolkosz, 2016).

Table 1. Bulk density and ratio of the manure with sand bedding by volume and weight at bone dry conditions

\begin{tabular}{c|c|c|c|c|c}
\hline & $\begin{array}{c}\text { Volume of } \\
\text { sample }\left(\mathbf{c m}^{\mathbf{3}}\right)\end{array}$ & $\begin{array}{c}\text { Weight of } \\
\text { sample }(\mathbf{g})\end{array}$ & $\begin{array}{c}\text { Bulk density } \\
\left(\mathbf{g ~ c m}^{-3}\right)\end{array}$ & $\begin{array}{c}\text { Ratio by volume } \\
\text { with total } \mathbf{( \% )}\end{array}$ & $\begin{array}{c}\text { Ratio by weight } \\
\text { with total }(\mathbf{\%})\end{array}$ \\
\hline Manure & 12400 & 4640 & 0.374 & 38 & 18 \\
Sand & 20500 & 21160 & 1.032 & 62 & 82 \\
Mixture & 32900 & 25800 & 0.716 & 100 & 100 \\
\hline
\end{tabular}

\section{Elemental analysis}

Table 2 shows the results of the elemental analysis of sand-separated dairy manure. Sand-separated manure proved to be 4 to 5 times higher in terms of elemental composition compared to a related study conducted by Mukhtar, Goodrich, and 
Capareda (2008). Available carbon is the most important constituent when dealing with biomass fuels. The majority of the contribution to the overall heating value comes from the carbon content. Sand-separated manure has $24.25 \%$ of carbon by weight. The removal of inorganic sand increased the carbon composition of manure. SLDN has a $\mathrm{C} / \mathrm{N}$ ratio of 19.67 , which is higher compared with the 14.71 ratio of sand-separated manure. In biogas production, a balanced $\mathrm{C} / \mathrm{N}$ ratio of feedstock favors an improved methane production system (Wu et al., 2010). An optimal $\mathrm{C} / \mathrm{N}$ ratio is about 20-30 (Yao and Miller, 2010; Wang et al., 2014). There should be of no need for sand separation if dairy manure will be used for composting or anaerobic digestion.

Table 2. Elemental analysis for sand-separated and sand-laden dairy manures

\begin{tabular}{c|c|c}
\hline Composition & $\begin{array}{c}\text { Experimental sand-separated manure } \\
\text { mean } \pm \text { SD }\end{array}$ & $\begin{array}{c}\text { Dairy manure with sand-bedding } \\
\text { mean } \pm \text { SD }\end{array}$ \\
\hline Available Carbon \% & $24.25 \pm 3.27$ & $5.9 \pm 0.70$ \\
Hydrogen \% & $2.73 \pm 0.32$ & $0.7 \pm 0.10$ \\
Nitrogen \% & $1.67 \pm 0.20$ & $0.3 \pm 0.00$ \\
Oxygen \% & $0.38 \pm 0.30$ & $0.24 \pm 1.00$ \\
Sulfur\% & $0.38 \pm 0.00$ & $0.1 \pm 0.00$ \\
\hline
\end{tabular}

*Mukhtar et al., 2008

Results for dairy manure composition and constituents vary widely across different conditions and areas in the United States (Wu, 2013; Wu et al., 2012). Variations can be mainly accounted to animal diet and nutrition, manure handling and storage techniques. Different animals produce different manure compositions (ASAE D384.2, 2005; Mukhtar, 2007).

\section{Heating value}

The High Heating Value (HHV) of the SLDM was $3.29 \mathrm{MJ} \mathrm{kg}^{-1}$. Upon removal of sand, the HHV increased up to $10.20 \mathrm{MJ} \mathrm{kg}^{-1}$. On another study, sand-separated dairy manure HHV was $9.1 \mathrm{MJ} \mathrm{kg}^{-1}$ (Nam et al., 2015). Dairy manure from University of Nebraska farms used for fluidized-bed gasification had a HHV of $11.6 \mathrm{MJ} \mathrm{kg}^{-1}$ (Wu et al., 2012). Based on these results, it is recommended to separate sand from the manure to attain better quality of biomass energy fuel. When compared to other biomass fuel, wood pellets have HHV of 17 to $23 \mathrm{MJ} \mathrm{kg}^{-1}$ (Leaver, 2001); poultry litter pellets 15.3 $\mathrm{MJ} \mathrm{kg}^{-1}$ and coal 20-30 $\mathrm{MJ} \mathrm{kg}^{-1}$ (Kuligowski, 2011).

\section{Pellet drying rate and durability test}

The drying characteristic of the dairy manure is shown in Figure 1. Convective drying was performed inside a SHERER Environmental Chamber. The average drying rate within the 20 -h drying period was measured to be at $0.025 \mathrm{~kg}$ moisture removed per $\mathrm{kg}$ of dried sample-hour. Decrease of the drying rate curve was observed beyond $20 \mathrm{~h}$ of drying time. The pellets were prepared based on different final moisture content with resulting drying times: 15\% MC (26.02 h); 10\% MC (29.53 h); 5\% MC (33.05 h) and $0 \% \mathrm{MC}(38.56 \mathrm{~h})$. 


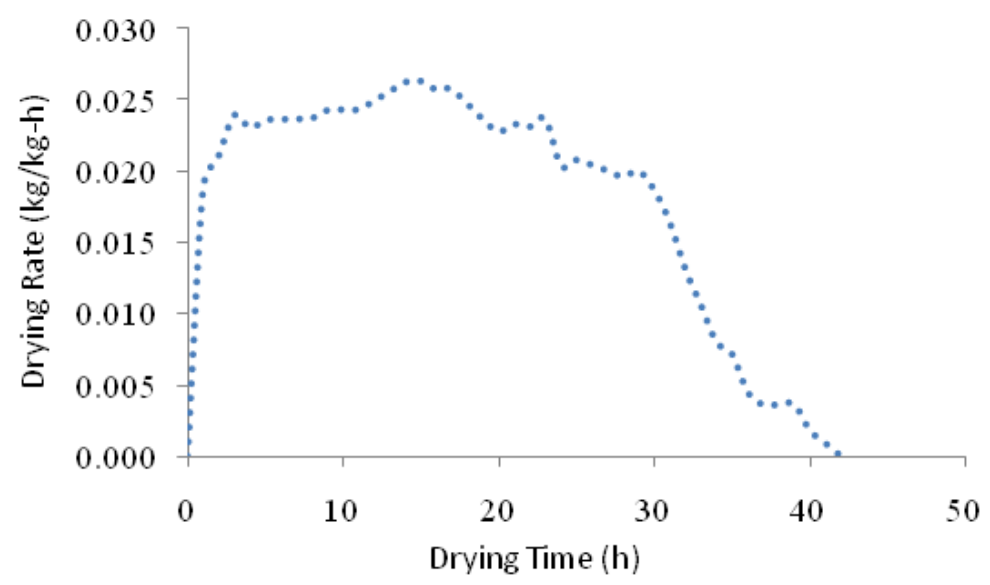

Figure 1. Drying curve for the preparation of dried dairy manure pellets

Studies conducted on biomass pellets for energy fuel show that the optimum moisture content of $10 \%$ to $15 \%$ can increase durability from $62 \%$ to $84 \%$ (Kaliyan and Morey, 2006). For wood and agricultural residues, the optimal range for MC is between $10 \%$ to $20 \%$ (O’Dogherty and Wheeler, 1984). These past results for energy pellets were used as the basis for this study.

The strength of the pellets is inversely proportional to the moisture content as shown in Figure 2. The pellets at $0 \% \mathrm{MC}$ level reached the breaking point after it was compressed for about $0.60 \mathrm{~cm}$. Both the $5 \%$ and $10 \% \mathrm{MC}$ levels pellets reached $1.04 \mathrm{~cm}$ compression before breakage. The $15 \% \mathrm{MC}$ level pellets had the highest compression displacement of $1.06 \mathrm{~cm}$ but with the lowest force tolerance of only $0.94 \mathrm{kgf}$. The $5 \% \mathrm{MC}$ level pellets can tolerate up to $1.90 \mathrm{kgf}$ while the $10 \% \mathrm{MC}$ level out at $1.66 \mathrm{kgf}$.

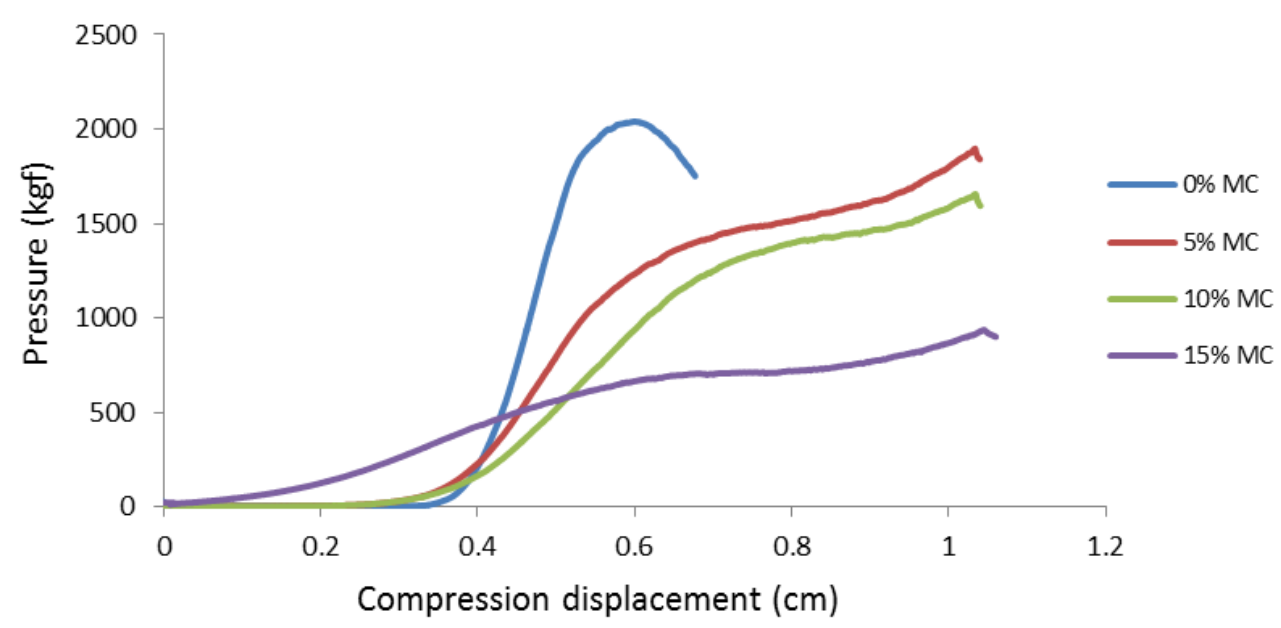

Figure 2. Compressive strength test for the pelletized manure at different moisture contents

The general trend of the MC level and compressive force interaction showed that increasing the moisture content decreased the pellet strength. On a micro level, the solid-solid interaction between manure particles is one factor that provides the ability to withstand pressure. The increase in moisture content increases the spacing between particles, thereby increasing the tendency for shearing (Zafari and Kianmehr, 2012). 
The shearing effect may have reduced the bonding forces between manure particles during pressure application.

Livestock manure moisture content for pelletizing was proposed to be optimal between $20 \%$ to $40 \%$ (Zafari and Kianmehr, 2012). However, the result was based on a sand-mixed manure system. The sand was observed to be finer particles compared to that of manure using \#45 mesh sieves. Since most of the fine particles were removed, there is a tendency for durability to decrease (Wilson, 2010). Observations on the pellets with higher MC seems to have the properties of polymer where it was broken easily but can still hold its form for a longer period as compared to the lower MC pellets that were stronger but once broken it will immediately collapse and disintegrate.

A one-factor three-level ANOVA was used for statistical analysis. The response parameter measured was the pressure tolerance $(\mathrm{kgf})$ of the pellets as indicated by the displacement of the MTS instrument. Figure $3 a$ shows that the resulting pressure readings are within the normal distribution region at $95 \%$ significance level. The predicted pressure values versus the actual values (Figure $3 b$ ) of the experiment are within the confidence region, resulting into a fit model with regression value of 0.975 .

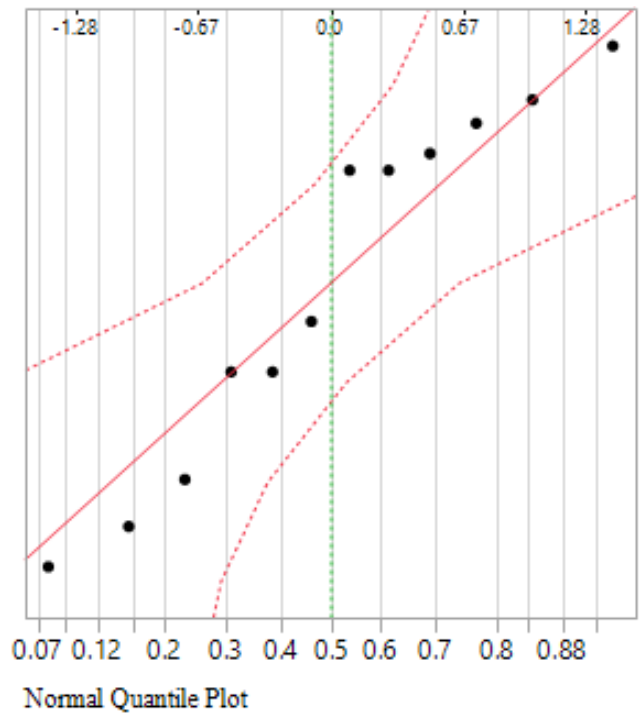

(a)

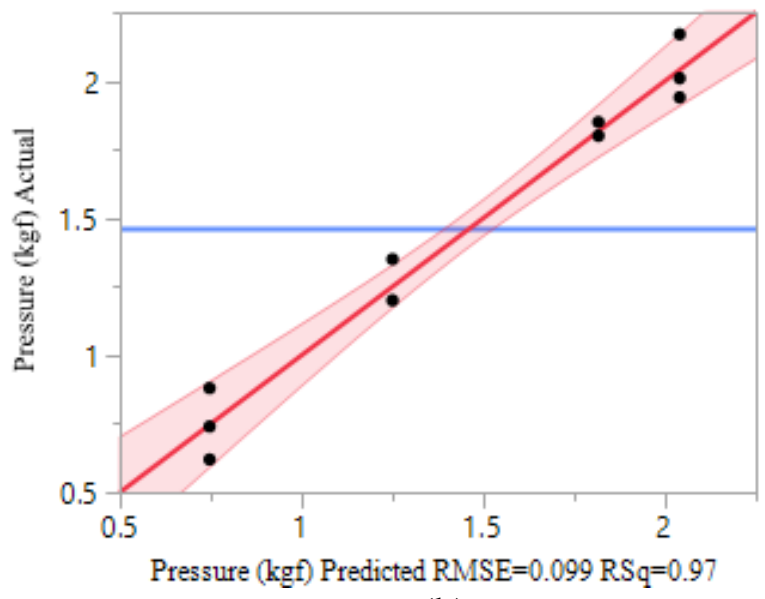

(b)

Figure 3. (a) Normal distribution and (b) predicted values for the pressure and moisture content interaction 
The test of the fit model significance showed that at 5\% level of significance (Table 3), the moisture content levels were found to statistically affect the strength of pellets ( $\mathrm{p}$-value $<0.0001$ ). Upon using ordered difference between resulting means, all moisture content levels were found to be significantly different. Only the $0 \%$ and $5 \%$ moisture levels were found to be statistically similar (Table 4). Moisture content of $15 \%$ falls out of the confidence levels range of compressive force of (1.12 kgf, $1.80 \mathrm{kgf})$, which shows that pellets should be prepared below 15\% MC level in order to withstand the given compressive force range. Dusting was observed to be minimal at 5\% and $10 \%$ MC level after compression tests. Within the resulting compression forces, the manure pellets are good candidates as biomass fuel thermal processing systems that produces power or energy. The mechanical properties of the prepared manure pellets can tolerate the mechanical handling and avoid dusting concerns commonly experienced by boiler systems in the power industry (Baxter, 2011).

Table 3. One-way ANOVA of pressure (kgf) applied at varying MCs (\%)

\begin{tabular}{c|c|c|c|c|c}
\hline Source & DF & Sum of squares & Mean square & F ratio & Prob $>$ F \\
\hline MC\% & 3 & 3.05 & 1.016 & 103.81 & $<0.0001^{*}$ \\
Error & 8 & 0.08 & 0.010 & & \\
C. Total & 11 & 3.13 & & & \\
\hline
\end{tabular}

*Significant different at $\alpha=0.05$

Table 4. Ordered difference between MC \% levels

\begin{tabular}{c|c|c|c}
\hline+ Level & - Level & Difference & p-Value \\
\hline 0 & 15 & 1.29 & $<0.0001^{*}$ \\
5 & 15 & 1.07 & $<0.0001^{*}$ \\
0 & 10 & 0.79 & $<0.0001^{*}$ \\
5 & 10 & 0.57 & $0.0005^{*}$ \\
10 & 15 & 0.50 & $0.0011^{*}$ \\
0 & 5 & 0.22 & 0.0928 \\
\hline
\end{tabular}

*Significant different at $\alpha=0.05$

\section{Conclusion}

Physical characteristics of sand-separated dairy manure pellets were investigated as a potential solid fuel in the form of pellets. Raw manure from dairy farms in Stephenville, TX was convectively dried and sand-separated prior to pelletizing. The average drying rate within the 20 -h drying period was measured to be at $0.025 \mathrm{~kg}$ moisture removed per $\mathrm{kg}$ of dried sample-hour. Decrease of the drying rate curve was observed beyond $20 \mathrm{~h}$ of drying time. Dried sand-free manure has better elemental and fuel characteristics compared with the SLDM. The dried dairy manure HHV of $10.20 \mathrm{MJ} \mathrm{kg}^{-1}$ is already comparable with existing biomass fuels. The resulting pellets can withstand $1.12 \mathrm{kgf}$ to $1.80 \mathrm{kgf}$ at $5-10 \% \mathrm{MC}$, which can be a candidate biomass fuel in terms of its elemental and durability properties.

One-way of effectively managing manure wastes is to prepare pellets after convective drying. This will either provide better income options for livestock farm owners or use the pellets for local heat or energy generation. However, to reach the 
optimum MC level for pellets, dryers should be made available to livestock owners rather than solely rely on air-drying. In terms of available technology, there are areas that can still be improved. Manure high initial MC and abrasive qualities are two main challenges that often result into high operating and equipment maintenance cost. Higher-moisture tolerant pelletizers may be developed to even potentially avoid the need for pre-drying.

Acknowledgement. The authors would like to thank the support of the Bioenergy Testing and Analysis Laboratory at Texas A\&M University, College Station and the unselfish cooperation of the Southwest Regional Dairy Center in Stephenville, Texas, USA. Likewise, the main author is indebted to the Fulbright Philippine-American Educational Foundation (PAEF) for the Advance Research Grant.

\section{REFERENCES}

[1] Aboltins, A., Kic, P. (2014): Comparison of two methods of poultry manure drying. Engineering for Rural Development 2014(5): 143-149.

[2] Allen, J., Farrah, M. (2005): Effect of Pelletized Poultry Manure on Vegetable. - DC Water Resources Research Institute, Washington D.C.

[3] Baxter, M. (2011): Biomass Fuel Quality. - Baxter Biomass Consultancy Ltd, England and Wales.

[4] Biomass Energy Center (2007): Wood Pellet Heating - Guidebook. A Reference on Wood Pellet Fuels \& Technology for Small Commercial \& Institutional Systems. Massachusetts Division of Energy Resources.

[5] Cantrell, K., Ro, K., Hunt, P. (2007): Livestock Waste-to-Energy Concepts. 701P0907cd. - ASABE, Broomfield, Colorado.

[6] Ciolkosz, D. (2016): PennState Extension. - Retrieved from Manufacturing Fuel Pellets from Biomass: http://extension.psu.edu/publications/uc203.

[7] EPA, U. (2004): Alternative Technologies/Uses For Manure. - Environmental Protection Agency, Washington D.C.

[8] Gardner, D., Poulsen, T., Felby, C. (2009): Importance of temperature, moisture content, and species for the conversion process of wood residues into fuel pellets. - Wood and Fiber Science 41: 414-425.

[9] Gerba, C., Smith, J. (2005): Sources of pathogenic microorganisms and their fate during land. - J. Environ. Qual. 34: 1 42-48.

[10] Gooch, C., Wedel, A. (2002): Effective Means of Handling Sand-Laden Dairy Manure. Cornell University, New York.

[11] Grimberg, S. (2008): Separation of Bedding Sand from Manure. - Clarkson University, New York.

[12] Hara, M. (2000): Fertilizer Pellets Made from Composted Livestock Manure. - Mie Prefectural Science and Technology Division Center, Mie, Japan.

[13] Kaliyan, N., Morey, R. (2006): Factors affecting the strength and durability of densified products. - Annual International Meeting of the ASABE, Portland, OR.

[14] Kuligowski, K. (2011): Alternative Manure Energy Solutions: Incineration and Thermal Gasification. - Pomeranian Center for Environmental Research and Technology, Poland.

[15] Leaver, R. (2001): Wood Pellet Fuel and Residential Market. - Northeast Regional Biomass Program, Washington D.C.

[16] Mani, S., Tabil, T., Sokhansanj, S. (2006): Effects of compressive force, particle size and moisture content on mechanical properties of biomass pellets from grasses. - Biomass and Bioenergy 30: 648-654. 
[17] McMullen, J., Fascina, O., Wood, C., Feng, Y. (2005): Storage and handling characteristics of pellets from poultry litter. - Applied Engineering in Agriculture 21(4): 645-651.

[18] Mukhtar, S., Goodrich, B., Capareda, S. (2008): Dairy Biomass as a Renewable Fuel Source. L-5494. - A\&M Agrilife Extension Publication, College Station, Texas.

[19] Nam, H., Maglinao, A., Capareda, S. (2015): Oxygen gasification and its syngas upgrading in a fluidized-bed reactor using sand mixed dairy manure. - ASABE Annual International Meeting (pp. 1-7), ASABE, Louisiana.

[20] O'Dogherty, M., Wheeler, J. (1984): Compression of straw to high densities in closed cylindrical dies. - J. Agric. Eng. Res. 29(1): 61-72.

[21] Romano, E., Brambilla, M., Bisaglia, C., Pedretti, E., Cavallo, E. (2014): Pelletization of composted swine manure solid fraction with different organic co-formulates: Effect of pellet physical properties on rotating spreader distribution patterns. - International Journal of Recycling of Organic Waste in Agriculture 3(4): 101-111.

[22] Tabil, L., Sokhansanj, S. (1996): Binding and Pelleting Characteristics of Alfalfa. CSAE (pp. 95-307). - Canadian Society of Agricultural Engineers, Mansonville, QC.

[23] Tumuluru, J., Conner, C., Hoover, A. (2016): Method to produce durable pellets at lower energy consumption using high moisture corn stover and a corn starch binder in a flat die pellet mill. - J. Vis. Exp. 112: e54092. DOI 10.3791/54092.

[24] Wilson, T. (2010): Factors Affecting Wood Pellet Durability. - PhD Thesis, Pennsylvania State University.

[25] Wu, H., Hanna, M., Jones, D. (2012): Fluidized-bed gasification of dairy manure by BoxBehnken design. - Papers and Publications 214, Biological Systems Engineering.

[26] Wu, X., Yao, W., Miller, Z. (2010): Biogas and CH4 productivity by co-digesting swine manure with three crop residues as an external carbon source. - Bioresour. Technol. 101: 4042-4047.

[27] Zafari, A., Kianmehr, M. (2012): Livestock manure management and pelleting. - Agric. Eng. Int.: CIGR Journal 14(3): 78-84. 